Article Type: Research Paper

\title{
Have Students Comprehended Investment?
}

\author{
Paskanova Christi Gainau ${ }^{1 *}$
}

\section{ㅁone}

\section{AFFILIATION:}

${ }^{1}$ Department of Accounting, Eben Haezar Economic School, North Sulawesi, Indonesia.

*CORRESPONDENCE:

paskanovagainau@stiebenzar.ac.id

THIS ARTICLE IS AVAILABLE IN:

http://journal.umy.ac.id/index.php/ai

DOI: 10.18196/jai.2103162

\section{CITATION:}

Gainau, P.C. (2020). Have Students Comprehended Investment?. Journal of Accounting and Investment, 21(3), 514-536.

\section{ARTICLE HISTORY}

Received:

12 Jun 2020

Reviewed:

15 Jun 2020

$7 \mathrm{Jul} 2020$

$29 \mathrm{Jul} 2020$

18 Aug 2020

Revised:

1 Jul 2020

$16 \mathrm{Jul} 2020$

17 Aug 2020

31 Aug 2020

Accepted:

31 Aug 2020

\author{
Abstract: \\ Research aims: This study aims to examine factors that influence stock \\ investment intention among students.
}

Design/Methodology/Approach: The population in this study are all individual student investors registered at the Indonesia Stock Exchange Investment Gallery in the North Sulawesi and Gorontalo Regions. Sample selection is based on the purposive sampling method. Data analysis was performed with SmartPLS 3.0 M3. Research findings: The results found that student attitudes are determined by employment opportunities in the capital market. In addition, attitudes and behavioral control also have significant effect on student intention. This is different with subjective norms which does not affect student investment intention.

Theoretical contribution/ Originality: This research confirm that job opportunity influences students attitude in stock investment. The attitude and perceived behavioral control support students intention to invest stock in capital market. Subjective norms does not effect to students intention, in the context of students in the North Sulawesi and Gorontalo Regions.

Practitioner/Policy implication: The implication is the universities need to make policies which is friendly with stock investment, such us Seminars, Workshops, Capital Market Schools, and Securities Traders Representative Courses (WPPE). The Indonesian Stock Exchange (Representative Office) and Exchange Members also need to increase an internship quota in order to support student investment intentions.

Research limitation/Implication: This study only examines the stage of student intentions because the sample is student whose main activity is studying and the additional activity is investing.

Keywords: Stock Investment; Job Opportunities; Investment Intentions; Partial Least Square.

\section{Introduction}

Investing stocks without appropriate education might lead students to become gamblers in capital markets. Education during university study can be a mean for students to pursue proper careers as investors and to contribute in capital market. Early investment amongst university students is country's vital spectrum for economic development (Akhtar \& Das, 2019). This situation is comprehended by the government, thus, the regulation of capital market which allows IDR 100,000 minimal balance for investment is introduced. However, this policy does not immediately encourage students to become investors. Their intentions to invest are influenced by psychological factors (Phan \& Zhou, 2014; Prawirasasra, 2016), mature and rational thinking (Rubaltelli, Pasini, Rumiati, Olsen, 
\& Slovic, 2010), accounting information (Aprillianto, Wulandari, \& Kurrohman, 2014; Prawirasasra, 2016), knowledge (Merawati \& Putra, 2015; Thai, Trang, \& Tho, 2017), risks, safety, wisdom, rumors, political news, and other people's consideration (Lubis, Sadalia, Fachrudin, \& Meliza, 2013).

As bank-based nation, Indonesians prefer to deposit their money in banks instead of capital markets (Choi \& Meek, 2013). Nevertheless, this paradigm has been shifting from bank-based to market-based since entering digital era 4.0. Report from ISE Representative Office in North Sulawesi Region explains that in September 2019 domestic investors have dominated Indonesian capital market. The province of North Sulawesi donated 10,063 investors per June 2019 divided into 4,500 investors from Manado City, followed by Minahasa Regency, and Bitung City ${ }^{1}$.

The escalation of domestic investor numbers needs to be supported by capital market education to avoid being snared in gambling actions. Therefore, to fulfill this necessity, Indonesian Stock Exchange cooperates with exchange members to organize seminars, talk shows, workshops, trainings, schools of capital markets in universities. Moreover, availabilities of investment gallery at campuses can be developed as literacy and education vessels of capital markets for students. Shaari, Hasan, Mohamed, \& Sabri, (2013) finds that proper literacy and education of capital market can advance investment analysis ability and prevent students from debts.

Ajzen (2011) illustrates a reason why an individual acts is because of attitudes (personal), subjective norms (environment), and behavioral controls. Associated with stock investment, Phan dan Zhou (2014) as well as Pahlevi and Oktaviani (2018) discover the presence of significant influences of attitudes, subjective norms, and behavioral controls in investment intentions. Furthermore, various researches which scrutinize student's willingness to invest in Indonesian stock market have been carried out (Tandio, Budiarta, \& Suardikha 2014; Prawirasasra, 2016; Pahlevi \& Oktaviani, 2018; Taufiqoh, Nur, \& Junaidi, 2019) unfortunately, limited studies were executed in the context of Western Indonesia.

During its 43 years of existence, capital market was newly introduced in Western Indonesia in 2011 started from the Province of Papua (Economy Okezone, 2011). Western Indonesia has inadequate numbers of public companies. Moreover, drawbacks caused by participation in fraudulent investment are experienced by majority of people. This results in the negative perspective about stock investment within society, including undergraduate students. Enormous number of students registered securities account as mandatory demanded by university without enthusiasm to invest. Stock investments are still regarded as gambling due to spreading rumors (Lubis et al., 2013). On the other hand, some of them invest because of the willingness to establish own company and to achieve dividend and capital gain (Croushore, 2006). This verifies that there are differences in condition and investment perspective among undergraduates.

\footnotetext{
${ }^{1}$ Laporan Kantor Perwakilan Bursa Efek Indonesia Wilayah Sulawesi Utara dan Gorontalo dalam acara Public Expo Live BEl, Agustus 2019.
} 
Digital era has impacted students' ability to critically analyze something prior to decision making, including investing. They tend to contemplate on long-term certainty factors during stock investment, such as job opportunities. Nurhayani (2012) discovers that students' intention to pursue a field of study is on account of existing employment opportunities. Job opportunities are a stage which will be experienced once students complete their study and have significant impact for their future career journey. Decision to invest is influenced by work availabilities in capital market. Therefore, this current study involves latent job opportunities as variables in capital market sector as an affecting variable toward students' attitudes.

Oyer (2008) addresses that stock movement in capital market possesses crucial impacts towards business students' career choices. Their decision to work in capital market depends on the market's condition. If the market displays excellent performances, students will be encouraged to pursue careers in it. This indicates the correlation between capital market's condition and job opportunities inside it.

Previous studies examined internal factors in capital market such as dividend amount (Croushore, 2006), investment literacy (Shaari et al., 2013), investment risks (Pahlevi \& Oktaviani (2018). Hence, current study includes additional variables as external factors in capital market but connected to students' decision such as employment opportunities, students' attitudes, and their environment.

The primary purpose of this study is to observe whether working chances affect students' investing attitudes, and whether these attitudes, subjective norms, and control behavior determine their intention to invest, and whether investment attitudes, subjective norms, and behavioral controls affect students' intentions to invest. The researcher has not yet reached the behavioral examination and investment decision stage because observed sample are undergraduates who prioritize studying and consider investment as extra activities. Investment among students is regarded as part of the learning process. This is noticeable from inefficient value of transaction. Transaction is considered as practicum of the subject taught in the classroom. Nevertheless, the research regarding students' willingness to invest holds significant value since every foundation of investment activities is motivation. Kim and Nofsinger (2008) assert that investors' motives impact on their decisions which later influence the capital market movement.

Stock price movement in capital market is determined by the number of stock demands and offers. If the capital market is dominated by gambling investors, its movement will be worsened. The reason is because investors only expect the raise of stock price and sell it without considering whether the company is crisis or not. Moreover, gamblers only estimate how to attain benefits from capital market without regarding company's sustainability. Djojopranoto and Mahadwartha (2016) find that investors in Indonesian capital market are prone to make irrational decisions. During uptrend state, biased behaviors indicated with gambler's fallacy and familiarity effect tend to occur. 
Motives behind stock trading action amongst university students must be acknowledged in order to formulate applicable strategy and policy to direct them to be proper not irrational investors (gambling), bully investment, and cultural follow-up. Survey carried out by NATIXIS (2016) addresses that approximately $32 \%$ investors failed to understand the goal of their action, whereas, $30 \%$ of investors employ their personal understanding and advisors' assistance. Rightful motivation will impact Indonesian capital market movements.

Practical contribution of this study is to advice higher education as educational vessels and Indonesian Stock Exchange as the regulators of Indonesian capital market to establish beneficial investment policies. Theoretical contribution is enrich the findings about stock investment intentions among college students.

\section{Literature Review and Hypotheses Development}

\section{Theory of Planned Behavior (TPB)}

Theory of planned behavior (TPB) is employed as theoretical model and framework since it has been applied and proven multiple times to capture the association between cognitive variables related to intentions TPB in this study will be applied to investigate relations among antecedent variables towards university students' enthusiasm to invest in capital markets. TPB is a branch of Theory of Reason Action (TRA) in which the differences are located on additional variables shown in TPB which is perceived behavior control variable (Ajzen, 2011).

TPB is an intention-based model developed by (Ajzen, 2011). It is used to demonstrate someone's purpose in acting in certain ways. Intention is an indicator of how serious an individual acts (Ajzen, 2011). Furthermore, it is the central factor of TPB. TPB postulates three independent predictors; the first is attitude which refers to how far a person possesses behavioral evaluation which is both advantageous and disadvantageous. The second is social factors called subjective norms which points to social pressure perceived whether to behave or not. The third is perceptual level of behavior control which focuses on the convenience and complication which control oneself to carry out an action. Generally, the more favorable attitude, and subjective norms, and the bigger control behavior perception, the stronger one's motivation is to perform the behavior under considerations (Ajzen, 2011). This study concentrates on TPB model by admitting job opportunities variable. The researcher identifies more significant variables towards a student's investment enthusiasm. Based on exposure mentioned above, following hypothesis are developed:

Job Opportunity are considered as accessible employment prospects in the future. Auyeung and Sands (1997), Tan and Laswad (2009), Odia and Ogiedu (2013) find that one's decision to pursue a sector is determined by obtainable employment prospect in it. 
If an occupation as a practitioner in capital market is always available, students might be interested to master it (Widowati \& Surjawati, 2015). Occupation chances in capital markets are broker, research analyst, investment banking, underwriter, investment manager, and marketing. These occupations require comprehensive awareness and knowledge. Hence, practitioners in capital market are required to attend various educations and complete trainings. Sarkar and Sahu (2017) address that contribution in capital market sectors without broad understanding comprises enormous consequences.

Stock investment is a type of different investments. Students as critical individuals will deliberate before determining their investment. Mauldin, Crain and Mounce (2000) discover one significant factor influencing students' decisions to focus on an area is potential income and employment market condition in that area.

The broad availabilities of job vacancies in capital market sector can increase students' enthusiasm to participate in stock investment because they are individuals who have not yet acquired the determination to seek employment. Therefore, when they learn something, they will perpend the upcoming impacts.

Associated with share investment, Bakhri (2018) serta Hermawati, Rizal and Mudhofar (2018) find that investment return is not a factor impacting students' investment intentions. This presents that return which is commonly the main target of investors in capital market is not the priority. Additionally, education received is late to provide information about return potential that students could gain when participating in capital market. However, this is not their main purpose. Favorable benefits regarded by them are available working chances in capital market area.

$\boldsymbol{H}_{1}$ : Job opportunities in capital market positively affect stock investment attitudes. Investment Attitudes

Schmidt (2010) defines attitude as an individual assessment of favorableness and unfavorableness from behavior object. In addition, it is regarded as one's belief about outcomes accomplished from participation in certain actions. Further, it is determined through one's faith about attitudes and consequences in carrying those actions out (Bobek \& Hatfield, 2003). Distinguish attitudes inflict different behaviors as well. Prior to attitudes, an individual must initially have motivation. Associated with stock investment, if students behave enthusiastically towards capital market, their intentions to invest will arise. Optimistic mindset is similar to love feeling where one reflects that capital market is something enjoyable and beneficial, and presents imminent crucial roles.

Tan and Laswad (2006), Van Hooft, Born, Taris, van der Flier, and Blonk (2004), Mirawati, Wardana, and Sukaatmadja (2016) find out that attitudes significantly inspire one's desire to determine particular decisions. It is comparable to investment determination. Akhtar and Das (2019) indicate that attitudes hold important roles in one's desire to multiply their assets. People who are encouraged to participate in stock investment are 
reinforced by their faiths that it will provide either short-term or long-term positive outcomes. This matter can trigger students' encouragement and decision to be involved in capital market world during their study in universities.

Additionally, attitudes importantly influence individuals' intentions to invest (Phan \& Zhou, 2014). This indicates that having interest in something emboldens one's inspiration to perform an action in order to satisfy one's ambition. Likewise, students' eagerness in investing in capital market is pushed by their likeness in this department.

$\boldsymbol{H}_{2}$ : Attitudes positively inspire stock investment intentions.

\section{Subjective Norms}

Subjective norms are described as external effects (Ajzen, 2011). These focus on an individual reference and belief about whether particular individual or group agrees or refuses to carry out actions, and how far a person is motivated to adapt herself/himself with other individual or group's beliefs (Bobek \& Hatfield, 2003). Tan and Laswad (2006) illustrate subjective norms as social pressures towards an individual to do or avoid specific behaviors. Related to share investment, students' decision to pursue that field is determined by surrounding people who are seen as role model, such as parents, educators, or colleagues (Fizer, 2013).

Students' motivation to invest in capital market is assumed to obtain encouragement or strain from other parties. Lubis et al., (2013), Nidar and Bestari (2012) identify that investment intentions are influenced by other parties' consideration, such as parents, families, close friends, lecturers, and colleagues. This pictures significant impacts of surrounding environments towards their motivation. What is more, the outcomes of a study carried out by Mirawati et al., (2016), Taufiqoh et al., (2019) claim that subjective norms occupy positive impacts to students' enthusiasm to make an investment.

\section{$\boldsymbol{H}_{3}$ : Subjective norms holds significant effects to stock investment intentions.}

\section{Perceived Behavior Controls}

TPB purifies TRA by involving the concepts of behavior controls (Ajzen, 2011). In TPB, perceived behavioral controls refer to individual control level which considers that he or she must be involved in particular attitudes (Bobek \& Hatfield, 2003). These type controls are unlike attitudes and subjective norms because they are non-motivational factors and represent a person's control level more than behavioral performance (Tan \& Laswad, 2006).

Bobek and Hatfield (2003) picture perceived behavior controls into 4 categories: resources, opportunities, impediments, and obstacles. Ariff, Bidin, Sharif, and Ahmad (2010) in their study, list them in confident, convenience, education, in control, skills and 
capabilities. Therefore, it is stated that students' investment behaviors can be controlled by resources (education, skills, capabilities, confident, convenience), opportunities, obstacles, and challenges.

Resources which can regulate students' willingness in stock investment are knowledge (Akhtar \& Das, 2019) and education/training of capital market (Tandio \& Widanaputra, 2016). This points out that if students possess knowledge/skills/capabilities, education, confident, efficient literature, and efficient equipment that supports transaction process (investment), thus, their optimism in investing will increase more. Hermanto (2017) stresses that students' must be provided with knowledge of how important to participate in investment in capital market are to increase their interests to act more in capital market.

Additionally, available opportunities for students to participate in Indonesian Stock Exchange or Securities Cooperation can advocate their optimism. On the other hand, obstacles and challenges in capital market can be risks. Risks play significant role in students' investment intentions (Tandio et al., 2014). Risks are indicators considered by university students before engaging in capital market investment. Mirawati et al., (2016) claim that perceived behavioral controls crucially determine students' willingness to invest in capital market.

In accordance with explanation above, hypothesis can be arranged as followings:

$\boldsymbol{H}_{4}$ : perceived behavioral controls significantly influence stock investment intention.

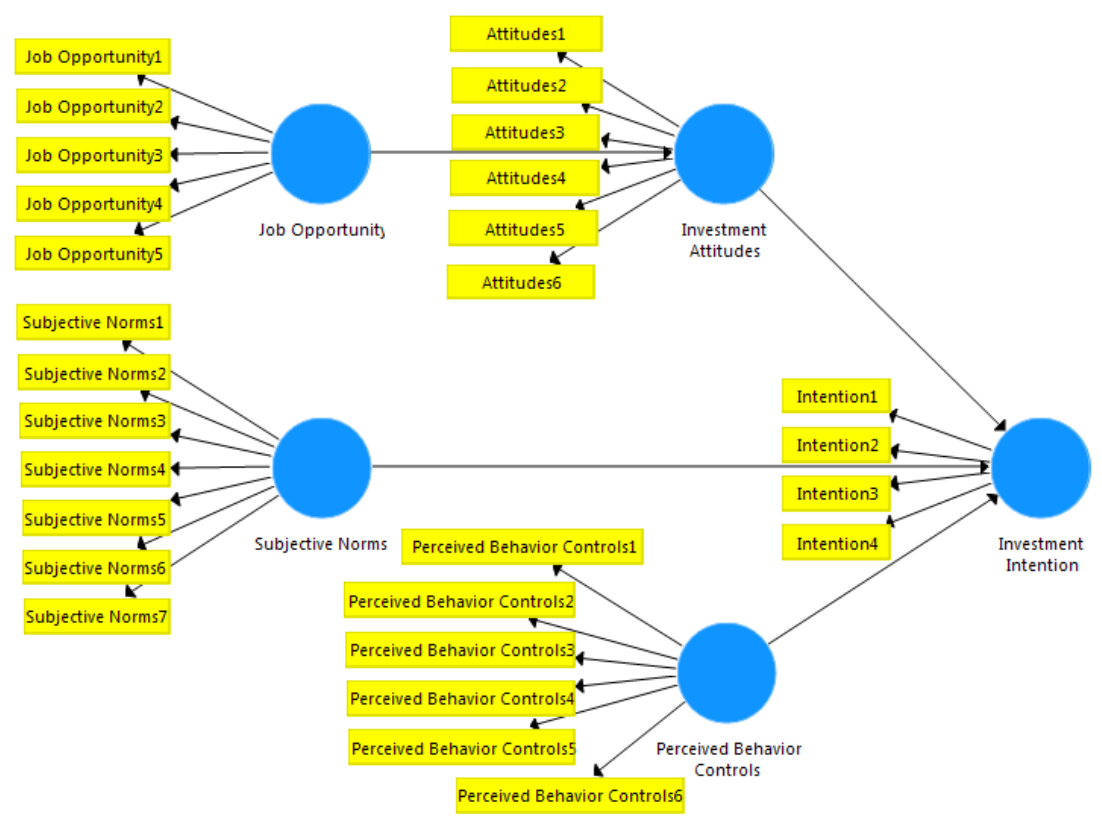

Figure 1 Research Model 


\section{Research Method}

\section{Population and Sample}

Research population is all higher education students registered as individual investors at Investment Galleries around campus. These galleries operate under the patronage of Representative Office of Indonesian Stock Exchange in the region of North Sulawesi and Gorontalo. Other investment Galleries near the campus are at University of Sam Ratulangi Manado, University of Manado State, University of Muhammadiyah Gorontalo, University of Gorontalo State, Community University of Manado, Polytechnic of Manado State, IAIN Manado, STIE Eben Haezar Manado, and STIE Petra Bitung. This study bases sampling with purposive sampling method with criteria: Active students from 2015 - 2019; Students who own securities account; students who are ctive in capital market transaction (minimum twice a month).

Online questionnaires are handed to all students. 107 respondents answered the questionnaire completely, but 7 respondents do not meet the criteria. Therefore, they are excluded from following analysis.

\section{Data Collecting Techniques}

Data collecting techniques such as survey uses instruments included in questionnaires and distributed to respondents. These instruments are developed by researchers based on previous studies. All of them have undertaken validity test, and the reliabilities use SmartPLS 3.0 M3.

\section{Definition of Operational Variable and Measuring Variable}

Job opportunity is potential future prospect which offers income, trainings, benefits, and work safety (Auyeung \& Sands (1997). This variable is measured by modifying employment prospect indicators used in the study of Tan and Laswad (2009). These variables employed 5 questions modified from Tan and Laswad's study (2009).

Investment attitudes are individual evaluation of favorableness and unfavorableness of attitude object (Schmidt, 2010). This variable is assessed using 6 indicators developed from prior researches (van Hooft et al., 2006; Schreurs, Derous, van Hooft, Proost, \& de Witte, 2009). These variables are measured with 6 questions.

Norms subjective is external references (Ajzen, 2011). It is measured with instruments representing each referents who were assigned as close friends to the individuals, such as families, close friends, colleagues, lecturers (Ariff et al., 2010; Bobek \& Hatfield, 2003); important people, and significant people (van Hooft et al., 2006; Van Hooft et al., 2004). The total of the question items employed in this measuring variable is 7 questions. 
Perceived behavior controls are individual control levels which envisage that one must be involved in certain behaviors (Bobek \& Hatfield, 2003). These variables are assessed by 5 indicators applied by (Ariff et al., 2010) in their study, which are confidence, convenience, education, control, and skills and capabilities. These variables are measured with 5 question items.

Investment intention is the indication of how serious someone is in doing something particular (Ajzen, 2011). This variable is calibrated with 4 indicators from various studies, which are time and effort, individual expectation, and applicants' inclination in seeking and pursuing job continuously (van Hooft et al., 2004). These variables are measured with 4 question items.

\section{Hypothesis Testing Techniques}

This study utilizes SEM method with a purpose to be able to capture causal association between variables in the model and to investigate whether model used can be assessed as appropriate predictors in mapping this study. SEM is an evolution of multiple equation model developed from econometric principles and combined with regulatory principles (factor analysis) of psychology and sociology (Hair, Black, Babin, \& Anderson 2010).

Research model testing is executed with software Smart PLS 3.0 M3 conditioning the number of maximal sample is 100 individuals. Analysis process is performed by testing the models entirely, and evaluating the compatibility of measurement model and structural model. For the measurement variable to be observed will be seen from its construct validity.

\section{Result and Discussion}

\section{Respondents' Characteristics}

Characteristics of student respondents who invested in capital market are examined in this study comprise sex, age, study program, and university year.

The average of 5 variables in this study show average number from moderate to high. According to this study, it can be concluded that the average value of all 5 variables adequately support study model. In addition, standard deviation of these variables indicates excellent findings because it is less than the average value of each indicator. Therefore, data distribution in this study is equal due to variance across data is not categorized high. 
Gainau

Have Students Comprehended Investment?

Table 1. Respondent Demographic

\begin{tabular}{|c|c|c|c|}
\hline & Respondent Demographic & Total & Percentage $(\%)$ \\
\hline \multirow[t]{2}{*}{ Sex } & Male & 30 & $30 \%$ \\
\hline & Female & 70 & $70 \%$ \\
\hline \multirow[t]{4}{*}{ Age } & $17-19$ years old & 17 & $17 \%$ \\
\hline & $20-22$ years old & 70 & $70 \%$ \\
\hline & $23-25$ years old & 7 & $7 \%$ \\
\hline & $>25$ years old & 6 & $6 \%$ \\
\hline \multirow[t]{5}{*}{ Department } & Accounting & 48 & $48 \%$ \\
\hline & Management & 35 & $35 \%$ \\
\hline & Business Administration & 10 & $10 \%$ \\
\hline & Syariah Banking & 4 & $4 \%$ \\
\hline & Economic Development & 3 & $3 \%$ \\
\hline \multirow[t]{5}{*}{ Year College } & 2015 & 12 & $12 \%$ \\
\hline & 2016 & 22 & $22 \%$ \\
\hline & 2017 & 51 & $51 \%$ \\
\hline & 2018 & 13 & $13 \%$ \\
\hline & 2019 & 2 & $2 \%$ \\
\hline \multirow{10}{*}{$\begin{array}{l}\text { Higher Education } \\
\text { Institution }\end{array}$} & Sam Ratulangi University & 16 & $16 \%$ \\
\hline & Manado State University & 9 & $9 \%$ \\
\hline & Muhammadiyah University of Gorontalo & 7 & $7 \%$ \\
\hline & Gorontalo State University & 3 & $3 \%$ \\
\hline & Community University of Manado Polytechnic of Manado State & 1 & $1 \%$ \\
\hline & IAIN Manado & 13 & $13 \%$ \\
\hline & STIE Eben Haezar Manado & 4 & $4 \%$ \\
\hline & STIE Petra Bitung & 41 & $41 \%$ \\
\hline & & 6 & $6 \%$ \\
\hline & Total of Respondent & 100 & $100 \%$ \\
\hline
\end{tabular}


Gainau

Have Students Comprehended Investment?

Table 2 Descriptive Statistics Indicators of Variable

\begin{tabular}{|c|c|c|c|c|c|c|}
\hline Indicator & Statement & Total & Min & Max & Mean & St.Dev \\
\hline Job Opportunity 1 & Extensive exposure to invest & 100 & 3 & 5 & 4.23 & 0.62 \\
\hline Job Opportunity 2 & Great opportunity to get a job in capital market & 100 & 2 & 5 & 4.0 & 0.7 \\
\hline Job Opportunity 3 & Income (salary) is high in the future & 100 & 2 & 5 & 4.0 & 0.8 \\
\hline Job Opportunity 4 & High social status & 100 & 1 & 5 & 3.4 & 0.8 \\
\hline Job Opportunity 5 & Broader employment opportunities & \multirow[t]{2}{*}{100} & 3 & \multirow[t]{2}{*}{5} & 4.1 & 0.7 \\
\hline Average of Job Opportunity & & & & & 3.9 & 0.7 \\
\hline Investment Attitudes1 & Challenging investment & 100 & 3 & 5 & 4.3 & 0.6 \\
\hline Investment Attitudes2 & Investment with good professionalism and image & 100 & 2 & 5 & 4.0 & 0.6 \\
\hline Investment Attitudes3 & $\begin{array}{l}\text { Investment with an important position in a } \\
\text { company ororganization }\end{array}$ & 100 & 3 & 5 & 4.1 & 0.7 \\
\hline Investment Attitudes4 & $\begin{array}{l}\text { The benefits when implementing stock } \\
\text { knowledge }\end{array}$ & 100 & 3 & 5 & 4.5 & 0.5 \\
\hline Investment Attitudes5 & Pleasant investment & 100 & 2 & 5 & 4.0 & 0.8 \\
\hline Investment Attitudes5 & The way to success & 100 & 2 & 5 & 3.7 & 0.7 \\
\hline Average of Attitudes & & & & & 4.1 & 0.7 \\
\hline Subjective Norm1 & Family supports and encourages me & 100 & 2 & 5 & 3.3 & 0.8 \\
\hline Subjective Norm2 & Close friendssupport and encourage me & 100 & 2 & 5 & 3.6 & 0.7 \\
\hline Subjective Norm3 & Colleagues support and encourage me & 100 & 2 & 5 & 3.6 & 0.6 \\
\hline Subjective Norm4 & Concern when family agrees / disagrees & 100 & 2 & 5 & 3.6 & 0.8 \\
\hline Subjective Norm5 & Concern when close friends agree / disagree & & 2 & 5 & 3.7 & 0.8 \\
\hline Subjective Norm6 & Concern when colleagues agree / disagree & 100 & 2 & 5 & 3.5 & 0.8 \\
\hline \multirow[t]{2}{*}{ Subjective Norm7 } & Concern when environment agree / disagree & 100 & 2 & 5 & 3.5 & 0.8 \\
\hline & & & & & 3.5 & 0.8 \\
\hline
\end{tabular}


Gainau

Have Students Comprehended Investment?

Table 2 Descriptive Statistics Indicators of Variable (cont)

\begin{tabular}{|c|c|c|c|c|c|c|}
\hline Indicator & Statement & Total & Min & Max & Mean & St.Dev \\
\hline Perceived Behavior1 & Personal confidence & 100 & 3 & 5 & 4 & 0.7 \\
\hline Perceived Behavior2 & Easy & 100 & 2 & 5 & 3.4 & 0.8 \\
\hline Perceived Behavior3 & Right education & 100 & 2 & 5 & 3.9 & 0.7 \\
\hline Perceived Behavior4 & Full control & 100 & 2 & 5 & 3.9 & 0.8 \\
\hline Perceived Behavior5 & Skills and capabilities & 100 & 2 & 5 & 3.6 & 0.6 \\
\hline Perceived Behavior6 & Difficulty or distress learning & 100 & 1 & 5 & 3.3 & 0.9 \\
\hline \multicolumn{3}{|c|}{ Average of Perceived Behavior Controls } & & & 3.7 & 0.7 \\
\hline Investment Intention 1 & Intention to devote much time to invest stock. & 100 & 2 & 4 & 3.1 & 0.6 \\
\hline Investment Intention2 & $\begin{array}{l}\text { Intention to study the techniques of investing } \\
\text { stock }\end{array}$ & 100 & 1 & 5 & 3.6 & 0.9 \\
\hline Investment Intention3 & Expect to get a return on investment & 100 & 1 & 5 & 3.9 & 0.9 \\
\hline Investment Intention4 & Continue to learn how to invest for profit & \multirow[t]{2}{*}{100} & 1 & \multirow[t]{2}{*}{5} & 3.6 & 1.0 \\
\hline Average of Intentions & & & & & 3.5 & 0.8 \\
\hline
\end{tabular}


The total average value of investment intentions 3.5 is classified as moderate. This clarifies that investment intentions need to be improved. The total average value of job opportunities (3.9), investment attitudes (4.1), and behavior controls (3.7) is categorized as high. Meaning, students have large perspective of job opportunities in capital market, investment attitudes, and behavior controls. Meanwhile, the average value of subjective norms (3.5) is considered as moderate which means students adequately receive external supports in stock investments.

\section{Outer Model (Measurement Model Fit)}

\section{Convergent Validity Test}

Convergent validity test aims to examine whether manifest variables of a construct highly correlated with other construct (Latan \& Ghozali, 2012). Its reflective indicator can be perceived by the value of loading factors and average variance extracted (AVE). Loading factor value is more 0.5 , and average variance extracted (AVE) is more than 0.4 (Hair et al. 2010).

Table 3 Loading Factors \& Crossloadings

\begin{tabular}{|c|c|c|c|c|c|}
\hline Indicator & $\begin{array}{c}\text { Job } \\
\text { Opportunity }\end{array}$ & $\begin{array}{l}\text { Investment } \\
\text { Attitudes } \\
\text { (IA) }\end{array}$ & $\begin{array}{l}\text { Subjective Norms } \\
\text { (SN) }\end{array}$ & $\begin{array}{c}\text { Perceived } \\
\text { Behavior } \\
\text { Control } \\
\text { (PBC) }\end{array}$ & $\begin{array}{l}\text { Investment } \\
\text { Intention } \\
\text { (II) }\end{array}$ \\
\hline J01 & 0.674 & 0.504 & 0.339 & 0.281 & 0.303 \\
\hline JO3 & 0.796 & 0.604 & 0.405 & 0.477 & 0.282 \\
\hline J05 & 0.819 & 0.564 & 0.327 & 0.341 & 0.219 \\
\hline IA1 & 0.420 & 0.638 & 0.389 & 0.320 & 0.210 \\
\hline IA2 & 0.519 & 0.770 & 0.396 & 0.464 & 0.362 \\
\hline IA3 & 0.555 & 0.650 & 0.423 & 0.262 & 0.221 \\
\hline IA4 & 0.487 & 0.708 & 0.219 & 0.366 & 0.376 \\
\hline IA5 & 0.432 & 0.638 & 0.342 & 0.507 & 0.303 \\
\hline IA6 & 0.549 & 0.671 & 0.324 & 0.403 & 0.344 \\
\hline SN1 & 0.447 & 0.437 & 0.710 & 0.409 & 0.309 \\
\hline SN2 & 0.439 & 0.427 & 0.754 & 0.424 & 0.311 \\
\hline SN3 & 0.268 & 0.258 & 0.605 & 0.218 & 0.168 \\
\hline SN4 & 0.125 & 0.162 & 0.622 & 0.197 & 0.141 \\
\hline SN5 & 0.184 & 0.272 & 0.605 & 0.232 & 0.130 \\
\hline SN6 & 0.196 & 0.296 & 0.667 & 0.236 & 0.073 \\
\hline SN7 & 0.182 & 0.340 & 0.661 & 0.206 & 0.118 \\
\hline PBC1 & 0.361 & 0.450 & 0.421 & 0.790 & 0.384 \\
\hline PBC2 & 0.318 & 0.389 & 0.280 & 0.757 & 0.354 \\
\hline PBC3 & 0.332 & 0.505 & 0.335 & 0.732 & 0.318 \\
\hline PBC4 & 0.396 & 0.343 & 0.329 & 0.714 & 0.294 \\
\hline PBC5 & 0.448 & 0.417 & 0.359 & 0.683 & 0.163 \\
\hline II1 & 0.324 & 0.353 & 0.224 & 0.299 & 0.679 \\
\hline 112 & 0.284 & 0.359 & 0.273 & 0.413 & 0.851 \\
\hline 113 & 0.300 & 0.408 & 0.261 & 0.332 & 0.878 \\
\hline 114 & 0.268 & 0.390 & 0.326 & 0.397 & 0.923 \\
\hline
\end{tabular}

Bold values are loadings for items which are above the recommended value of 0.6 
Gainau

Have Students Comprehended Investment?

Table 4 Result of Validity Test

\begin{tabular}{|c|c|c|c|}
\hline Construct & Indicator & Loading Factors & AVE \\
\hline \multirow[t]{3}{*}{ JO } & J01 & 0.674 & 0.586 \\
\hline & $\mathrm{JO3}$ & 0.796 & \\
\hline & $\mathrm{JO5}$ & 0.819 & \\
\hline \multirow[t]{6}{*}{ IA } & IA1 & 0.638 & 0.463 \\
\hline & $\mathrm{IA} 2$ & 0.770 & \\
\hline & IA3 & 0.650 & \\
\hline & IA4 & 0.708 & \\
\hline & IA5 & 0.638 & \\
\hline & IA6 & 0.671 & \\
\hline \multirow[t]{7}{*}{ SN } & SN1 & 0.710 & 0.439 \\
\hline & SN2 & 0.754 & \\
\hline & SN3 & 0.605 & \\
\hline & SN4 & 0.622 & \\
\hline & SN5 & 0.605 & \\
\hline & SN6 & 0.667 & \\
\hline & SN7 & 0.661 & \\
\hline \multirow[t]{5}{*}{ PBC } & PBC1 & 0.790 & 0.542 \\
\hline & PBC2 & 0.757 & \\
\hline & PBC3 & 0.732 & \\
\hline & PBC4 & 0.714 & \\
\hline & PBC5 & 0.683 & \\
\hline \multirow[t]{4}{*}{ II } & II1 & 0.679 & 0.702 \\
\hline & 112 & 0.851 & \\
\hline & 113 & 0.878 & \\
\hline & 114 & 0.923 & \\
\hline
\end{tabular}

Discriminant Validity Test

Discriminant validity test aims to ensure distinguish construct manifest variables does not highly correlated. Its reflective indicators can be observed from the cross loading value of each item. Cross landing value must be above 0.6 (Latan \& Ghozali, 2012). Table 5 presents the conclusion of convergent and discriminant validity test.

Table 5 Result of Discriminant Validity

\begin{tabular}{lccccc}
\hline \multicolumn{1}{c}{ Construct } & 1 & 2 & 3 & 4 & 5 \\
\hline Investment Attitudes & 0.681 & & & & \\
Investment Intention & 0.451 & 0.838 & & & \\
Job Opportunity & 0.531 & 0.349 & 0.765 & & \\
Perceived Behavior Control & 0.569 & 0.433 & 0.485 & 0.736 & \\
Subjective Norms & 0.508 & 0.326 & 0.468 & 0.465 & 0.663 \\
\hline
\end{tabular}

Reliability Test

Reliability test aims to justify the accuracy, consistency, precision of instruments in measuring constructs. Construct reliability measurement with reflective indicators can be completed by observing the value of composite reliability and cronbach's alpha. The value of composite reliability must be more than 0.7 , whereas, cronbach's alpha must be larger than 0.60 (Hair et al. 2010). 
Gainau

Have Students Comprehended Investment?

Table 6 Result of Reliability Test

\begin{tabular}{|c|c|c|c|c|c|}
\hline $\begin{array}{c}\text { Laten } \\
\text { Variable }\end{array}$ & Indicator & $\begin{array}{c}\text { Composite } \\
\text { Reliability } \geq \\
0.60\end{array}$ & $\begin{array}{l}\text { Cronbach's } \\
\text { Alpha } \geq 0.60\end{array}$ & $\begin{array}{l}\text { Loading } \\
\text { Range }\end{array}$ & Conclusion \\
\hline $\begin{array}{l}\text { Job } \\
\text { Opportunity }\end{array}$ & $\begin{array}{l}\mathrm{JO1}, \mathrm{JO3} \\
\mathrm{JO5}\end{array}$ & 0.808 & 0.643 & $0.674-0.819$ & Reliable \\
\hline $\begin{array}{l}\text { Investment } \\
\text { Attitudes }\end{array}$ & $\begin{array}{l}\text { IA1, IA2, IA3 } \\
\text { IA4, IA5, IA6 }\end{array}$ & 0.838 & 0.768 & $0.638-0.770$ & Reliable \\
\hline $\begin{array}{l}\text { Subjective } \\
\text { Norms }\end{array}$ & $\begin{array}{l}\text { SN1, SN2, SN3, SN4, } \\
\text { SN5, SN6, SN7, }\end{array}$ & 0.845 & 0.819 & $0.605-0.754$ & Reliable \\
\hline $\begin{array}{l}\text { Perceived } \\
\text { Behavior } \\
\text { Control }\end{array}$ & $\begin{array}{l}\text { PBC1, PBC2, PBC3, } \\
\text { PBC4, PBC5 }\end{array}$ & 0.855 & 0.794 & $0.683-0.790$ & Reliable \\
\hline $\begin{array}{l}\text { Investment } \\
\text { Intention }\end{array}$ & $\begin{array}{l}\|11,\| 2 \\
\|3,\| 4\end{array}$ & 0.903 & 0.853 & $0.679-0.923$ & Reliable \\
\hline
\end{tabular}

\section{Common Method Variance Test}

Common method variance test targets to prevent the occurrences of errors in data measurement and evaluation. One factor causing errors in data measurement is method variance. This study employs single factor test techniques to show the existence of this issue. Evaluation findings suggest no single factor explaining more than $50 \%$ which indicate no manifestation of CMV (Abdi, Chin, Vinzi, Russolillo, \& Trinchera, 2013). The findings are evident in this path. Moreover, variance is no more than $50 \%$ only $30.2 \%$ which designates no CMV in this research.

Table 7 Result of Common Method Variance

\begin{tabular}{|c|c|c|c|c|c|c|}
\hline \multicolumn{7}{|c|}{ Total Variance Explained } \\
\hline \multirow[t]{2}{*}{ Component } & \multicolumn{3}{|c|}{ Initial Eigenvalues } & \multicolumn{3}{|c|}{ Extraction Sums of Squared Loadings } \\
\hline & Total & $\%$ of Variance & $\begin{array}{c}\text { Cumulative } \\
\%\end{array}$ & Total & $\%$ of Variance & $\begin{array}{c}\text { Cumulative } \\
\%\end{array}$ \\
\hline 1 & 7.550 & 30.202 & 30.202 & 7.550 & 30.202 & 30.202 \\
\hline 2 & 2.977 & 11.908 & 42.110 & & & \\
\hline 3 & 1.972 & 7.889 & 49.999 & & & \\
\hline 4 & 1.493 & 5.971 & 55.970 & & & \\
\hline 5 & 1.371 & 5.483 & 61.453 & & & \\
\hline 6 & 1.185 & 4.738 & 66.191 & & & \\
\hline 7 & .983 & 3.932 & 70.123 & & & \\
\hline 8 & .857 & 3.428 & 73.552 & & & \\
\hline 9 & .822 & 3.286 & 76.838 & & & \\
\hline 10 & .702 & 2.810 & 79.647 & & & \\
\hline 11 & .650 & 2.601 & 82.248 & & & \\
\hline 12 & .586 & 2.344 & 84.592 & & & \\
\hline 13 & .549 & 2.196 & 86.788 & & & \\
\hline 14 & .510 & 2.041 & 88.829 & & & \\
\hline 15 & .432 & 1.728 & 90.557 & & & \\
\hline 16 & .398 & 1.591 & 92.147 & & & \\
\hline 17 & .359 & 1.435 & 93.582 & & & \\
\hline 18 & .322 & 1.286 & 94.868 & & & \\
\hline 19 & .291 & 1.166 & 96.034 & & & \\
\hline 20 & .264 & 1.055 & 97.089 & & & \\
\hline 21 & .208 & .831 & 97.920 & & & \\
\hline 22 & .151 & .603 & 98.524 & & & \\
\hline 23 & .146 & .583 & 99.107 & & & \\
\hline 24 & .114 & .458 & 99.565 & & & \\
\hline 25 & .109 & .435 & 100.000 & & & \\
\hline Extraction $\mathrm{M}$ & : Principa & Component Analy & & & & \\
\hline
\end{tabular}




\section{Gainau}

Have Students Comprehended Investment?

\section{Inner Model (Structural Model Fit)}

In assessing structural model with PLS, it starts by evaluating R-Square for each endogen latent variables as predicting power of structural model. The values of R-Square 0.75 , 0.50 , and 0.25 shows that strong, moderate, and weak models represent enormity of construct variance number explained by the models (Latan \& Ghozali, 2012). R-Square value of investment attitude variable as $Y_{1}$ is 0.542 meaning that model is categorized in moderate category while investment intention variable as $Y_{2}$ is 0.230 is classified in weak category (Latan \& Ghozali, 2012).

Figure 2 shows the path analysis test results while Table 8 explains the structural model fit test result. It can be seen that Job Opportunities hold positive influence of 0.739 . This is shown with t-statistic number of 16.331. Meanwhile, investment attitudes, subjective norms, and behavior control affect investment intentions described by t-statistic 2.050 and 2.334. Subjective norms are proven to be ineffective in altering students' investment intentions in capital market shown with the value of $t$-statistic 0.553 .

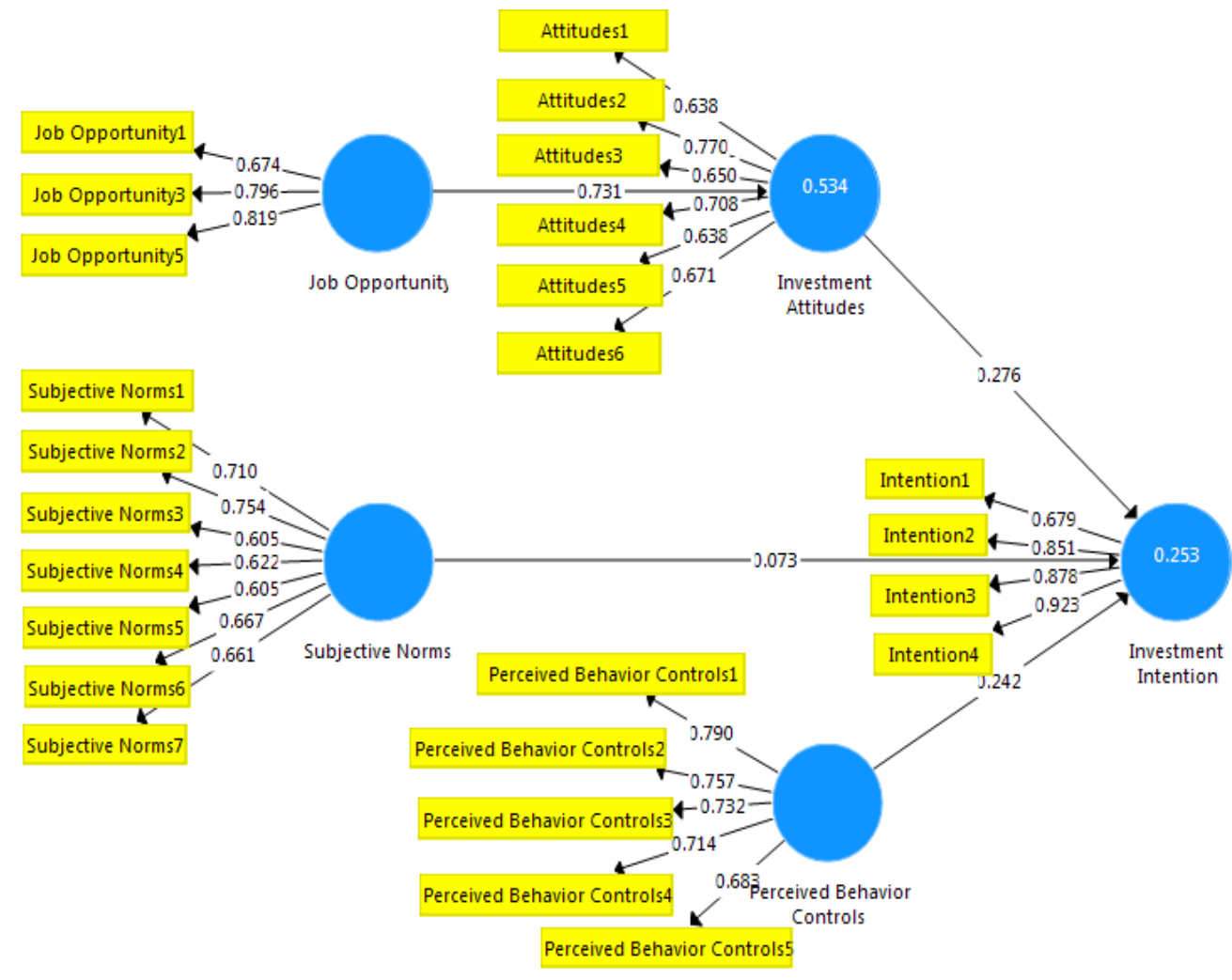

Figure 2 Result of the path analysis 
Table 8 Test Result of Structural Model Fit

\begin{tabular}{clcccc}
\hline Hypothesis & \multicolumn{1}{c}{ Path } & $\begin{array}{c}\text { Total } \\
\text { Effects }\end{array}$ & $\begin{array}{c}\text { T-statistic } \\
\geq 1,96\end{array}$ & p-value & Supported \\
\hline $\mathrm{H}_{1}$ & Job Opportunity $\rightarrow$ Attitude & 0.739 & 16.331 & 0.000 & Yes \\
$\mathrm{H}_{2}$ & Attitudes $\rightarrow$ Intention & 0278 & 2.050 & 0.041 & Yes \\
$\mathrm{H}_{3}$ & Subjective Norm $\rightarrow$ Intention & 0073 & 0.553 & 0.581 & No \\
$\mathrm{H}_{4}$ & Perceived Control $\rightarrow$ Intention & 0.242 & 2.334 & 0.020 & Yes \\
\hline
\end{tabular}

Employment opportunities in capital market sector are ascertained to obtain positive effects on students' attitudes to make an investment in capital market. The broader job opportunities in capital market, the greater the levels of students' investment attitudes are. The availability of broad job vacancies can expand students' enthusiastic attitudes to contribute as active investors. Vice versa, when there are limited chances, their attitudes toward investment will decrease. Further, students' disregard benefits which they receive after investing (Bakhri, 2018; Hermawati et al., 2018), but they are more interested to career prospect availaible in capital market.

North Sulawesi is categorized as a province in Western Indonesia with enormous job vacancies. This is evident from Participation Level of Workforce of North Sulawesi which continuously increase year by year (sulut.bps.go.id). The facts show that job hunters are increasing, particularly university students. This is regarded as something unusual because students are critical individuals and tend to consider the future to ensure whether present contribution will reward them or not. Furthermore, the final purpose after graduating university is to work. This is the main reason why students tend to notice job vacancies in the future before deciding to participate in capital market.

Oyer (2008) perceives that when capital modal is in outstanding state, students decide to seek employment in capital market. This indicates students are critical individuals in seeing the condition of job market where working intention in capital market is enthused by market's performance. If this performance is not effective, they will not be interested to seek job in this area. The availability of job opportunities in capital market affects students' interests in investment since university. On one hand, if students wish to invest because of available employment, it will not last long. When the situation in capital market becomes negative, they will switch to different occupation. Investment attitudes only emboldened by working chances prove that students have not yet acknowledged investment.

University students' intentions to invest in capital market are affected by their attitudes with the value of $t$-statistic $2,050<t$-table 1.96 . A student's attitudes to invest support their intentions to invest in capital market. This behavior determines their optimism to invest in capital market. This finding agrees with Pahlevi and Oktaviani (2018) and Phan and Zhou (2014) which indicate that willingness to participate in investing in capital market is determined by their attitudes. Correspondingly, this confirms Theory of Planned Behavior developed by Ajzen (2011) that motivation is imposed by attitudes. Likewise, all investment actions carried out by university students in North Sulawesi and Gorontalo are directed personally. Student investors are responsible for their action personally. Thus, they need to control themselves in stock investment. One solution is to 
collaborate with ISE Representative Office and Exchange Members to frequently organize capital market education. The purpose of this action is to guide better students' investing actions. The longer they commit in investment, the more knowledge and understanding they acquired regarding proper investment. This study ascertains that stock investment movements among undergraduates are determined personally rather than externally. Similarly Sapitri and Yaya (2015) confirm that students' optimism is stirred by their eagerness to learn.

In addition, their motivation to invest in capital market is not determined by subjective norms (reference) with the value of $t$-statistic $0.553<\mathrm{t}$-table 1.96 . This finding empirically confirms that this motive is not affected by support, pressure, or other external considerations such as parents, families, close friends, lecturers, and colleagues. It is evident that opening securities account done by undergraduates is not because of lecturers' demands. It is associated with academic discipline in learning process in a classroom in order to pass the subject. This result is approved by the findings of Akhtar and Das (2019), Sartika, Hasan, Said, and Najib, (2018) which claim that subjective norms are not crucial in affecting learners' optimism in investment.

University students in North Sulawesi prioritize earning own income. It is noticeable from large number of students having part time jobs while studying. Job opportunities entered are diverse. This demography illustrates that university students are independent as decision making is based on personal consideration. Mature age and tendency to have personal perspective are included as factors influencing their actions. Their independences show that investing is not based on external opinion. This objects the findings of Pahlevi and Oktaviani (2018) dan Taufiqoh et al., (2019). Dissimilar results are because previous research samples are Capital Market Study Group which is generally well educated concerning capital market investment. Those classified in this group are likely to acquire external factors (lectures and friends) who master capital market. Hence, investment intention seems to be straightforwardly directed.

Students' determination to invest in capital market is shaped by behavioral control with value $\mathrm{t}$-statistic $2.334<\mathrm{t}$-table 1.96 . This shows that resources, opportunities, obstacles, and challenges faced do not impact this investing determination. Resources such as capital market education, skills and capabilities, confidence, library literature, stock exchange laboratory (investment gallery) and application availability as well as transaction equipment are not postulated to strengthen students' investing intentions. Every investment gallery in a higher education holds a chance to collect education from ISE Representative Office and Exchange Members. Moreover, literature referring to capital market is administered by ISE Representative Office in order to assist in improving students' skills and confidences in stock investment

In addition, opportunities granted to those individuals to be involved in annual event such as Indonesian Investment Festival (Investival) organized by Indonesian stock exchange and exchange members are not justified to have effect their will to invest. This runs diverse types of competitions such as Capital Market Quiz, Capital Market and Economy Debate, Emiten Hunting, Capital Market Vlog, Capital Modal Pageant. 
Increased intentions in investing aftermath contribution in Investival are evident. Additionally, involvement in annual internship at ISE Representative Office in North Sulawesi and Gorontalo stimulates students' enthusiasm. On the other hand, impediments and challenges encountered in capital market such as investment risks are proven to be effective to students' investment intentions. This clarifies the findings of Tandio et al., (2014), Mirawati et al., (2016), Pahlevi and Oktaviani (2018). Likewise, Theory of Planned Behavior developed by Ajzen (2011) is confirmed to present similar outcome.

\section{Conclusion}

This study aims to investigate whether job opportunities drive students' investment attitudes, and whether these attitudes, subjective norms, behavior controls shape their intentions to stock investment. 100 student investors from 9 higher education institutions in North Sulawesi are employed in this study. Study findings indicate that attitudes in investing stock among student will be more positive if supported by the availabilities of immense job opportunities in capital market. Broader career prospects in capital market can inspire students to learn stock investment. All actions are determined individually rather than externally. Thus, students are seen as individuals who have acknowledged investment because their intentions are determined personally. However, self-control must be mastered in order to avoid gambling or becoming gamblers. Behavioral controls plays important role in shaping students' optimism of stock investments.

Theoretically, this study approves Theory of Planned Behavior that motives behind willingness to carry out something are attitudes and behavioral controls. In context of stock investment among students, job opportunities determine investment attitudes. In addition, both attitudes and behavioral controls affect students' intentions to invest. Meanwhile, subjective norms inefficiently influence these enthusiasms.

On the other hands, an empirical implication of current study is that higher education is obligated to design benevolent regulation in stock investment through the development of capital market education such as guest lecturers, seminar, workshop, and school of capital market. Moreover, students should be facilitated in securities brokerage representative course for stock investment to appear to have impacts on their upcoming careers. This kind of education policy aids them to control themselves in stock investment. This can instigate the eagerness in stock investment. ISE Representative Office is recommended to organize regulation to include students to work in stock exchange for example increasing internship quotas in order to deliver not only investment theory but also to be included in workforce related to investing. Moreover, higher education institutions and Indonesian Stock Exchange Representative Office are mandated to establish collaboration to present qualified education related to capital market earlier in order to embolden students' knowledge about investment. This education can be dispersed to the public; hence, the people can distinguish legitimate investment from illegal one. 


\section{Gainau}

Have Students Comprehended Investment?

This study has a limitation that is it only examines the stage of student's intention to invest due to the research samples are passive investors. Following studies are recommended to investigate their attitudes towards investing by employing investors who are active in stock investment. Proceeding studies are suggested to evaluate the stage of investment behaviors by prioritizing investors as the major samples.

\section{References}

Abdi, H., Chin, W. W., Vinzi, V. E., Russolillo, G., \& Trinchera, L. (2013). New Perspectives in Partial Least Squares and Related Methods. Springer Proceedings in Mathematics and Statistics, 56. https://doi.org/10.1007/978-1-4614-8283-3

Ajzen, I. (2011). The theory of planned behaviour: Reactions and reflections. Psychology and Health, 26(9), 1113-1127. https://doi.org/10.1080/08870446.2011.613995

Akhtar, F., \& Das, N. (2019). Predictors of investment intention in Indian stock markets: Extending the theory of planned behaviour. International Journal of Bank Marketing, 37(1), 97-119. https://doi.org/10.1108/1JBM-08-2017-0167

Aprillianto, B., Wulandari, N., \& Kurrohman, T. (2014). Perilaku Investor Saham Individual Dalam Pengambilan Keputusan Investasi : Studi Hermeneutika-Kritis. E-Joumal Ekonomi Bisnis dan Akuntansi, 1(1), 16-31. https://doi.org/10.19184/ejeba.v1i1.567

Ariff, A. H., Bidin, Z., Sharif, Z., \& Ahmad, A. (2010). Predicting Entrepreneurship Intention Among Malay University Accounting Students in Malaysia. Universiti Tun Abdul Razak e-Journal, 6(1), 1-10. Retrieved from http://www.myjurnal.my/public/browse-journal-view.php?id=293

Auyeung, P., \& Sands, J. (1997). Factors influencing accounting students' career choice: A cross-cultural validation study. International Journal of Phytoremediation, 21 (1), 13-23. https://doi.org/10.1080/096392897331596

Badan Pusat Statistika. (2020). Badan Pusat Statistika Provinsi Sulawesi Utara. Retrieved from https://sulut.bps.go.id/

Bakhri, S. (2018). Minat Mahasiswa dalam Investasi di Pasar Modal. Al-Amwal: Jurnal Ekonomi dan Perbankan Syari'ah, 10(1), 146-157. https://doi.org/10.24235/amwal.v10i1.2846

Bobek, D. D., \& Hatfield, R. C. (2003). An Investigation of the Theory of Planned Behavior and the Role of Moral Obligation in Tax Compliance. Behavioral Research in Accounting 15(1), 13-38). https://doi.org/10.2308/bria.2003.15.1.13

Choi, F. D. ., \& Meek, G. K. (2013). International Accounting Seventh Edition. Journal of Chemical Information and Modeling, 53(9), 1-3. https://doi.org/10.1017/CBO9781107415324.004

Croushore, D. (2006). Money and Banking: A Policy oriented approach. Cengage Learning.

Djojopranoto, R. R., \& Mahadwartha, P. A. (2016). Pengujian Bias Perilaku : Gambler's Fallacy, Halo Effect, dan Familiarity Effect di Pasar Modal Indonesia. Jurnal Akuntansi dan Keuangan Indonesia, 13(2), 142-159. http://dx.doi.org/10.21002/jaki.2016.08

Fizer, D. (2013). Factors Affecting Career Choices of College Students Enrolled in Agriculture. The Master of Science in Agriculture and Natural Resources Degree. Retrieved from https://www.utm.edu/departments/msanr/ pdfs/Fizer Research Project Final.pdf

Hair Jr., J.F., Black, W.C., Babin, B.J. \& Anderson, R.E. (2010). Multivariate Data Analysis: A Global Perspective. 7 th Edition, Pearson Education, Upper Saddle River. 


\section{Gainau}

Have Students Comprehended Investment?

Hermanto. (2017). Perilaku Mahasiswa Ekonomi Di Universitas Esa Unggul. Jumal Ekonomi, $8(2), 1-12$. Retrieved from https://ejurnal.esaunggul.ac.id/index.php/Eko/article/view/1733

Hermawati, N., Rizal, N., \& Mudhofar, M. (2018). Analisis Faktor - Faktor yang Mempengaruhi Minat Mahasiswa untuk Berinvestasi di Pasar Modal (Studi pada Mahasiswa Prodi Akuntansi STIE Widya Gama Lumajang). Progress Conference, 1(1), 850-860. Retrieved from http://proceedings.stiewidyagamalumajang.ac.id/index.php/progress/article/view/73

Kim, K. A., \& Nofsinger, J. R. (2008). Behavioral finance in Asia. Pacific Basin Finance Journal, 16(1-2), 1-7. https://doi.org/10.1016/i.pacfin.2007.04.001

Latan, H., \& Ghozali, I. (2012). Konsep, Teknik dan Aplikasi SmartPLS 2.0 M3 untuk Penelitian Empiris. Semarang: Badan Penerbit Universitas Diponegoro.

Lubis, A. N., Sadalia, I., Fachrudin, K. A., \& Meliza, J. (2013). Perilaku Investor Kenangan. USU Press.

Mauldin, S., Crain, J. L., \& Mounce, P. H. (2000). The Accounting Principles Instructor's Influence on Students' Decision to Major in Accounting. Journal of Education for Business, 75(3), 142-148. https://doi.org/10.1080/08832320009599005

Merawati, L. K., \& Putra, I. P. M. (2015). Kemampuan Pelatihan Pasar Modal Memoderasi Pengaruh Pengetahuan Investasi dan Penghasilan Pada Minat Berinvestasi Mahasiswa. Jurnal Ilmiah Akuntansi dan Bisnis, 10(1), 105-118. Retrieved from https://ojs.unud.ac.id/index.php/iiab/article/view/16825

Mirawati, N. M., Wardana, I. M., \& Sukaatmadja, I. P. G. (2016). Pengaruh Sikap, Norma Subjektif, dan Persepsi Kontrol Keperilakuan, Terhadap Niat Siswa SMK di Kota Denpasar untuk Menjadi Wirausaha. E-Jurnal Ekonomi dan Bisnis Universitas Udayana, 7(5), 1981-2010. Retrieved from https://ojs.unud.ac.id/index.php/EEB/article/view/16273

Natixis. (2016). Retrieved from https://www.im.natixis.com/eninstitutional/resources/2016-global-individual-investor-survey

Nidar, S. R., \& Bestari, S. (2012). Personal Financial Literacy Among University Students (Case Study at Padjadjaran University Students , Bandung, Indonesia). World Journal of Social Sciences, 2(4), 162-171. Retrieved from http://www.feb.unpad.ac.id/dokumen/files/Personal-Financial-Literacy-AmongUniversity-Students TURNITIN.pdf

Nurhayani, U. (2012). Pengaruh Motivasi Terhadap Minat Mahasiswa Akuntansi Untuk Mengikuti Pendidikan Profesi Akuntansi (PPAk). Jurnal Mediasi, 4(1), 59-67. Retrieved from

https: $/ / \mathrm{www}$. google.com/url? sa $=t \& \mathrm{rct}=j \& q=\& e s r \mathrm{c}=\mathrm{s} \&$ source $=$ web $\& \mathrm{~cd}=\& \mathrm{cad}=\mathrm{rja}$ \&uact=8\&ved=2ahUKEwjroLyQqtbrAhVDXSsKHfaqCRoQFjAAegQIAxAB\&url= http $\% 3 \mathrm{~A} \% 2 \mathrm{~F} \% 2 \mathrm{~F}$ digilib.unimed.ac.id $\% 2 \mathrm{~F} 417 \% 2 \mathrm{~F} 1 \% 2 \mathrm{FFulltext}$.pdf\&usg=AOvVaw 0KGG4bSn2RUF0MbrgIPdI7

Odia, J. O., \& Ogiedu, K. O. (2013). Factors Affecting the Study of Accounting in Nigerian Universities. Journal of Educational and Social Research, 3(3), 89-96. https://doi.org/10.5901/jesr.2013.v4n3p89

Oyer, P. (2008). The making of an investment banker: Stock market shocks, career choice, and lifetime income. Journal of Finance, 63(6), 2601-2628. https://doi.org/10.1111/j.1540-6261.2008.01409.x

Pahlevi, R. W., \& Oktaviani, I. I. (2018). Determinants of Individual Investor Behaviour in Stock Investment Decisions. AFRE (Accounting and Financial Review), 1(2), 53-61. https: / / search.crossref.org/?q $=+2598-7771$ \&published $=2018$ \&page $=2$ 


\section{Gainau}

Have Students Comprehended Investment?

Phan, K. C., \& Zhou, J. (2014). Factors Influencing Individual Investor Behavior : An Empirical Study of the Vietnamese Stock Market. American Journal of Business and Management, 3(2), 77-94. https://doi.org/10.11634/216796061403527

Prawirasasra, K. P. (2016). Behavioral Finance in Investment Decision-Making. International Journal of Management and Applied Science, 2(7), 27-29. Retrieved from http://ijmas.iraj.in/paper_detail.php?paper_id=5015\&name=Behavioral_Finance_In Investment Decision-Making Process

Rubaltelli, E., Pasini, G., Rumiati, R., Olsen, R. A., \& Slovic, P. (2010). The Influence of Affective Reactions on Investment Decisions. Journal of Behavioral Finance, 11(3), 168176. https://doi.org/10.1080/15427560.2010.507409

Sapitri, Z., \& Yaya, R. (2015). Faktor-Faktor Yang Berpengaruh Terhadap Minat Mahasiswa Untuk Mengikuti Pendidikan Profesi Akuntansi (PPAk). Jurnal Akuntansi \& Investasi, 16(1), 46-61. Retrieved from https://journal.umy.ac.id/index.php/ai/article/view/1347

Sarkar, A. K., \& Sahu, T. N. (2017). Factors Influencing Behaviour of Individual Investor in Stock Market: A Case Study in West Bengal. IMS Business School Presents Doctoral Colloquium, 32-39. http://www.managejournal.com/up/conference/20170210152302.pdf

Sartika, S., Hasan, M., Said, A.M.I., \& Najib, M.. (2018). Faktor-Faktor yang Mempengaruhi Minat Mahasiswa Berinvestasi di Galeri Investasi Universitas Negeri Makasar. Prosiding Seminar Nasional Pendidikan Ekonomi, 447-454. Retrieved from http://snpe.fkip.uns.ac.id/2018/10/19/prosiding-seminar-nasional-pendidikanekonomi-2018/

Schmidt, N. (2010). What Drives Investments into Mutual Funds? Applying the Theory of Planned Behaviour to Individuals' Willingness and Intention to Purchase Mutual Funds. Retail Investment Conference, July, 1-39. Retrieved from https://www.retailinvestmentconference.org/files/eric submission full 5 schmidt v 0.pdf

Schreurs, B., Derous, E., van Hooft, E. A. J., Proost, K., \& de Witte, K. (2009). Predicting applicants' job pursuit behavior from their selection expectations: The mediating role of the theory of planned behavior. Journal of Organizational Behavior, 30(6), 761-783. https://doi.org/10.1002/job.570

Shaari, N. A., Hasan, N. A., Mohamed, R, K. M. H., \& Sabri, M. A. J. M. (2013). Financial Literacy: a Study Among the University Students. Interdisciplinary Journal of Contemporary Research In Business, 5(2), 279. Retrieved from https: $/ / \mathrm{www} . \mathrm{google} . \mathrm{com} / \mathrm{url}$ ? $\mathrm{sa}=\mathrm{t} \& \mathrm{rct}=\mathrm{i} \& \mathrm{q}=\& \mathrm{esrc}=\mathrm{s} \&$ source $=\mathrm{web} \& \mathrm{~cd}=\& \mathrm{cad}=\mathrm{rja}$

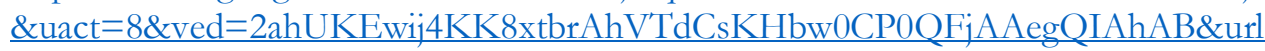
$=$ https $\% 3 \mathrm{~A} \% 2 \mathrm{~F} \% 2 \mathrm{Fjournal}$-archieves 33 .webs.com $\% 2 \mathrm{~F} 279$ 299.pdf\&usg=AOvVaw21bG7si7AkZhXTkESj-Z0O

Tan, M. L. M., \& Laswad, F. (2006). Students' beliefs, attitudes and intentions to major in accounting. Accounting Education, 15(2), 167-187. https://doi.org/10.1080/09639280600787194

Tan, M. L. M., \& Laswad, F. (2009). Understanding Students' Choice of Academic Majors: A Longitudinal Analysis. Accounting Education, 18(3), 233-253. https://doi.org/10.1080/09639280802009108

Tandio, D.R., Budiarta, I. K., \& Suardikha, I. M. S. (2014). Pengaruh Modal Investasi Minimal di BNI Sekuritas, Return dan Persepsi Terhadap Risiko Pada Minat Investasi Mahasiswa, dengan Penghasilan Sebagai Variabel Moderasi (Studi Kasus Pada Mahasiswa Magister di Fakultas Ekonomi dan Bisnis Universitas Udayana). E-Jumal 


\section{Gainau}

Have Students Comprehended Investment?

Ekonomi dan Bisnis Universitas Udayana, 3(7), 377-390. Retrieved from https://ojs.unud.ac.id/index.php/EEB/article/view/7992

Tandio, T., \& Widanaputra, A. (2016). Pengaruh Pelatihan Pasar Modal, Return, Persepsi Risiko, Gender, dan Kemajuan Teknologi Pada Minat Investasi Mahasiswa. E-Jurnal Akuntansi, 16(3), 2316-2341. Retrieved from https://ojs.unud.ac.id/index.php/Akuntansi/article/view/21199

Taufiqoh, E., Nur, D., \& Junaidi. (2019). Pengaruh Norma Subjektif, Motivasi Investasi, Pengetahuan Investasi, Persepsi Return dan Literasi Keuangan Terhadap Minat Mahasiswa Berinvestasi Saham di Pasar Modal. Jurnal Ilmiah Riset Akuntansi, 8(1), 1-13. Retrieved from http://riset.unisma.ac.id/index.php/jra/article/view/4063

Thai, P., Trang, M., \& Tho, N. H. (2017). International Journal of Economics and Financial Issues Perceived Risk, Investment Performance and Intentions in Emerging Stock Markets. International Journal of Economics and Financial Issues, 7(1), 269-278. Retrieved from https://www.econjournals.com/index.php/ijefi/article/view/3381

Van Hooft, E. A. J. Van, Born, M. P., Taris, T. W., \& Flier, H. Van der. (2006). Ethnic and gender differences in applicants decision making processes: An application of the theory of reasoned action. International Journal of Selection and Assessment, 14(2), 156-166. http://search.ebscohost.com/login.aspx?direct $=$ true\&db=eoah\&AN=24338136\&site =ehost-live

Van Hooft, E. A. J., Born, M. P., Taris, T. W., van der Flier, H., \& Blonk, R. W. B. (2004). Predictors of Job Search Behavior Among. American Psychological Association., 57(1), 2559. Retrieved from https://psycnet.apa.org/doi/10.1111/j.1744-6570.2004.tb02483.x

Widowati, A. I., \& Surjawati, S. (2015). Studi Tentang Keputusan Memilih Jurusan S1 Akuntansi (Studi Empiris Pada Mahasiswa Program Studi S1 Akuntansi Universitas Semarang). Jumal Dinamika Sosial Budaya, 17(1), 1-11. https://doi.org/10.26623/jdsb.v17i1.498 